\title{
METHOD OF AUTOMATIC TRANSMISSION OF THE INTEGRITY BREACH SIGNALS OF THE RIVER LOCAL DIFFERENTIAL SUBSYSTEM
}

DOI: $10.36724 / 2072-8735-202|-| 5-4-42-48$

Aleksandra A. Ivanova,

Admiral Makarov State University of Maritime and Inland Shipping, St. Petersburg, Russia, uid@gumrf.ru

Sergei F. Shakhnov,

Admiral Makarov State University of Maritime and Inland Shipping,

St. Petersburg, Russia, shahnovsf@gumrf.ru
Manuscript received 22 December 2020;

Accepted 28 January 2021

Keywords: integrity of the navigation system, integrity breach, local differential subsystems, reference station, alarm signal, differential correction, AIS

The integrity of the navigation system is one of the important factors affecting the safety of navigation. Currently, on the inland waterways of Russia, alerts on the integrity of the GLONASS global navigation satellite system (GNSS) are transmitted through river local differential subsystems (LDSS), which include one or more reference stations. Industrial interference from industrial zones and power lines, mutual interference from neighboring reference stations and, especially, the inhomogeneity of the underlying surface affect the range of the reference stations, which leads to the integrity breach of the differential field and transmission of unreliable corrective information to the navigator. However, the navigator is not notified of the incorrect operation of the reference stations. As a result, inaccurate corrective information leads to errors in calculating the vessel position, which reduces the level of navigation safety. A method for the automatic transmission of notifications about the LDSS integrity breach from a remote control and management station (RCMS) to the ship is presented in the paper. The structure of the message transmitting the notification signal has been formed. Criteria characterizing the quality of the differential correction signal are presented. Possible combinations of such criteria, which determine the performance of the differential mode of the reference station, are identified. Each combination of criteria is juxtaposed the corresponding notification texts displayed on the monitors of the LDSS operators and on the navigator's display. A scheme for the automatic transmission of an alarm message from a remote control point through the RCMS, the regional command and control center, the vessel traffic control center and base stations of the automatic identification system (AIS) to ship transponders has been developed. As a result, the developed method for transmitting the alarm message containing combinations of quality criteria for the differential correction signal allows to automatically inform the navigator about the reliability of the corrective information transmitted by one or another reference station.

Information about authors:

Aleksandra A. Ivanova, Admiral Makarov State University of Maritime and Inland Shipping, postgraduate of Navigation on Inland Waterways Department, St. Petersburg, Russia

Sergei F. Shakhnov, Admiral Makarov State University of Maritime and Inland Shipping, professor of Navigation on Inland Waterways Department, St. Petersburg, Russia

Для цитирования:

Иванова А.А., Шахнов С.Ф. Способ автоматической передачи сигналов нарушения целостности речной локальной дифференциальной подсистемы // T-Сomm: Телекоммуникации и транспорт. 202I. Том 15. №4. С. 42-48.

For citation:

Ivanova A.A., Shakhnov S.F. (202I) Method of automatic transmission of the integrity breach signals of the river local differential subsystem. T-Comm, vol. 15, no.4, pp. 42-48. (in Russian) 


\section{Introduction}

The effectiveness of any navigation system is characterized by its accuracy, availability, continuity and integrity. In terms of the navigation safety, integrity is one of the most important factors. The integrity of the global navigation satellite system (GNSS) is its ability for a given time interval and with a given probability to provide consumers with alarms about the unreliability of GNSS navigation signals. Without confidence in the system integrity, there is no way to know if the information being received is correct.

GNSS augmentation systems improve the positioning accuracy of objects in differential mode and allow you to monitor the integrity of GNSS such as GPS (USA), GLONASS (Russia), Galileo (EU) and BeiDou (China).

The US Coast Guard DGPS Service provides GPS and DGPS integrity breach alarms within 10 seconds of detecting a failure [1]. Safety of Life (SoL) service of Europe's regional satellitebased augmentation system - EGNOS, provides 6 seconds warning of system failures [2-4].

Currently, on the inland waterways of Russia, notifications about the integrity of the GLONASS GNSS are transmitted through the local differential subsystems. The time during which such notifications should be transmitted is regulated by IMO resolution A.915 (22) and should not exceed 10 seconds [5]. Reference stations (RS), which are the basis of the river local differential subsystem (LDSS), are also capable to transmit notifications about the failure of any equipment that is part of their composition. However, notifications that, due to certain factors, the range of the RS has changed, and it no longer covers the required section of the waterway, which means that the integrity of the differential correction (DC) field in this place is breached, are not transmitted. Therefore, the problem of transmitting this type of notifications to the user arises.

Taking into account the strict requirements for the frequency of monitoring the integrity of differential field in the river conditions, the transmission time of such signals for most inland waterways should not exceed 6 seconds. The use of vessel traffic service dispatchers or operators of river stations for monitoring distress messages for the transmission of such notifications in the differential field monitoring and control system (M\&CS) proposed in articles [6-8] cannot provide the required notification rate. The article [9] described the structural diagram of an automatic system for transmitting signals of the integrity breach of the LDSS from a remote control and management station (RCMS) to the ship, but the means by which the transmission of such signals becomes possible were not presented.

\section{Methods and materials}

Navigation data transmission is governed by the Radio Technical Commission for Maritime Services (RTCM) standards. In particular, Special Committee-104 (SC-104) has developed standards for functioning the differential global navigation satellite system (DGNSS). The standards of 2.0-3.3 versions regulate the format for transmitting corrective information (RTCM messages). Initially, the standard was being developed for the transmission of corrections to GPS signals (version 2.0), then the standard was expanded by the transmission of corrections to GLONASS signals (version 2.2), and in version 3.2, the trans- mission of corrections to the signals of the navigation satellite systems BeiDou, Galileo and to the signals of Quasi-Zenith Satellite System QZSS was added.

The standard of 1.2 version regulates the transmission format of another type of message - RSIM-messages, and was developed for the reference and control stations of the GPS differential subsystem. The RSIM standard was originally written for maritime LDSS, but then it was successfully implemented in the Eurofix system [10-12].

Also, this committee standardizes the RINEX navigation data exchange format independent of the receiver model and the protocol for transmitting RTCM messages over the Internet - Ntrip (version 10.0-10.1) [13-14].

Thus, there are two formats for data transmission in DGNSS: RTCM and RSIM. The article [15] describes the use of RSIM messages for the information exchange between the control station (CS) and an additionally created remote control station. The authors introduced a new non-standardized data transfer format between the CS and the remote control station, using the known structure of RSIM messages, and successfully tested it. This fact has demonstrated the possibility of using RSIM messages not only for transmitting data between the RS and CS, but also for transmitting notifications in the M\&CS of LDSS.

Table 1

Basic RSIM messages and their functions

\begin{tabular}{|c|c|c|c|c|}
\hline $\begin{array}{c}\text { RSIM } \\
\text { message } \\
\text { No. }\end{array}$ & Function & RS & IMS & CS \\
\hline 1 & $\begin{array}{c}\text { Requesting a specific RSIM message } \\
\text { and setting its transfer interval }\end{array}$ & Receives & Receives & Transmits \\
\hline 2 & $\begin{array}{c}\text { Alarm when receiving } \\
\text { an unidentified message }\end{array}$ & Transmits & Transmits & Receives \\
\hline 3 & Parameters reset control & Receives & Receives & Transmits \\
\hline 5 & $\begin{array}{c}\text { Diagnostic Report / Hardware Fault } \\
\text { Alert }^{1}\end{array}$ & Transmits & Transmits & Receives \\
\hline 6 & GPS receiver parameters & Receives & Receives & Transmits \\
\hline 7 & GPS satellites parameters & \begin{tabular}{|l|} 
Transmits \\
/Receives \\
\end{tabular} & \begin{tabular}{|l|} 
Transmits \\
/Transmits \\
\end{tabular} & $\begin{array}{c}\text { Receives } \\
1-\end{array}$ \\
\hline 8 & Satellites health management & Receives & Receives & Transmits \\
\hline 9 & GPS satellites status & Transmits & Transmits & Receives \\
\hline 10 & $\begin{array}{l}\text { RS data transmission channel } \\
\text { parameters }\end{array}$ & Receives & - & Transmits \\
\hline 11 & RS alarm thresholds & Receives & - & Transmits \\
\hline 12 & $\mathrm{R}$ alarms & Transmits & - & Receives \\
\hline 13 & RS corrective data & Transmits & - & Receives \\
\hline 14 & $\begin{array}{l}\text { IMS data transmission channel } \\
\text { parameters }\end{array}$ & - & Receive & Transmits \\
\hline 15 & IMS data transmission channel status & - & Transmits & Receives \\
\hline 16 & IM alarm thresholds & - & Receives & Transmits \\
\hline 17 & IM alarms & - & Transmits & Receives \\
\hline 18 & $\begin{array}{c}\text { Integral control of differential mode } \\
\text { status (DGPS) }\end{array}$ & - & Tran mits & Receives \\
\hline 19 & Integral control of corrective data & - & Transmits & Receives \\
\hline 20 & System feedback of IMS with RS & Receives & Transmits & - \\
\hline 21 & RS almanac parameters & Receives & - & Transmits \\
\hline 22 & RTC messages broadcast schedule & Receives & - & Transmits \\
\hline 23 & Universal RTCM message & $\begin{array}{c}\text { Receives / } \\
-\end{array}$ & $\begin{array}{c}-1 \\
\text { Transmits } \\
\end{array}$ & \begin{tabular}{|l} 
Transmits \\
/Receives
\end{tabular} \\
\hline 24 & Transmitter status and controlling it & - & - & Transmits \\
\hline 25 & Radio transmission control and status & - & - & Transmits \\
\hline 26 & General text message & \begin{tabular}{|l|} 
Transmits \\
/Receives
\end{tabular} & $\begin{array}{l}\text { Transmits } \\
\text { /Receives } \\
\end{array}$ & $\begin{array}{l}\text { Transmits } \\
\text { /Receives }\end{array}$ \\
\hline
\end{tabular}

${ }^{1}$ Data transmission is carried out in ASCII format 
The RSIM standard [16] describes the performance, functional parameters, interface and environment parameters for DGNSS reference station and was developed to ensure consistency among GNSS differential service providers. The RSIM standard defines the number of RSIM messages that provide communication between the various equipment of reference station (RS), integrity monitoring station (IMS) and control station (CS) regardless of the manufacturer.

At the moment, 99 types of RSIM messages have been standardized, of which messages 1 to 27 are used for GPS mode, and 51 to 55 - for GLONASS mode; messages 28 to 50 are reserved for DGPS mode, and messages 56 to 99 are reserved for DGLONASS and GALILEO. Some of the used RSIM messages are presented in table 1.

It should also be noted that RSIM messages 1-8 and 10-27 are also used for DGLONASS. Fig. 1 shows the RSIM messages transmission between the RS, IMS and CS.

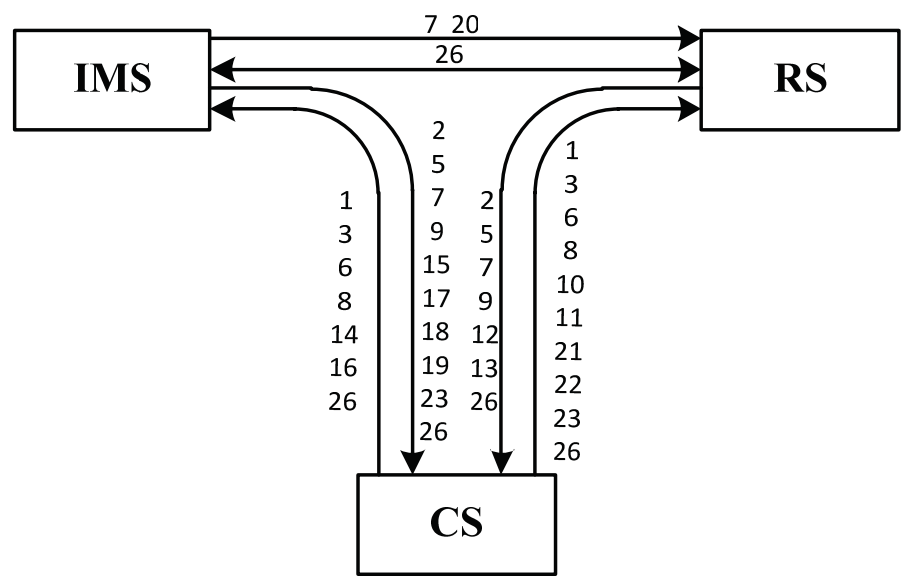

Fig. 1. RSIM messages flow

Each RSIM message begins with the address field "\$ PRCM" and the message type (its number), and ends with a separator “*”, a checksum "hh" and a separator for the end of the sentence " $<\mathrm{CR}><\mathrm{LF}>$ " [16]. Thus, the structure of the RSIM message is represented as follows:

\$PRCM, N, x.x, .. * *hh $<\mathrm{CR}><\mathrm{LF}>$,

where $\mathrm{N}$ - number of the transmitted RSIM message; x.x, . . - fields of the RSIM message depending on its type.

\section{Results}

Already standardized messages RSIM\#12 and RSIM\#17 can serve as a prototype of the structure of a message that transmits an alert signal in the M\&CS. The first message is used by the reference station to transmit the alarm signals that appear in it to the control station. The second message also contains alarm signals sent to the CS, but here the sender is the IMS. These standardized messages, in addition to the message type ("N" in formula (1)), differ in the content and number of fields "x.x, . . .”. RSIM\#12 has 5 such fields, and RSIM\#17 has 12.

The first field for both types of messages is used to transmit the alarm time, which is specified as UTC time (Coordinated Universal Time). Therefore, it is advisable to use the purpose of this field also in the generated non-standardized message for transmitting the notification signal in the M\&CS.

The rest of the fields in messages RSIM\#12 and RSIM\#17 are used to transmit the various types of alarms. For example, exceeding the threshold value of the pseudorange correction, which is calculated in the RS, or a low signal level in the correction information receiving channel located in the IMS.

In the M\&CS, the quality of the differential correction signal at the border of the reference station coverage area is checked according to three criteria, namely:

1) the electr field intensity of the signal at the receiving point $E_{s}$ should be higher than the receiver sensitivity $E_{\min }$;

$2)$ the signal-to-noise ratio $\left(E_{s} / E_{n}\right)$ must exceed the threshold value $M$;

3) the error probability of an element-by-element reception of a digital message $\left(p_{\text {err }}\right)$ should not exceed the permissible value $\left(p_{\max }\right)$.

The first two parameters are determined at the remote control points (RCP) of the M\&CS installed on the calculated boundaries of the reference station coverage areas, and the last one is calculated in the RCMS. Thus, if all three criteria are met, then the differential correction signal at the calculated boundary of the reference station coverage area will be correctly decoded by the users' navigation equipment, the integrity of the differential field is preserved, and the user can use the corrective information transmitted by this RS when calculating his position. Otherwise, when at least one of the criteria is not met, the M\&CS should send an alarm signal that will notify the user that the integrity of the differential field is breached, the range of the reference station has changed, therefore, it is impossible to use the corrective information transmitted by this RS.

Taking into account the existing criteria for assessing the quality of the differential correction signal, the structure of a non-standardized message containing an alarm in the M\&CS is as follows:

$$
\text { \$PRCM , N, hhmmss.ss, } \underset{1}{a}, \underset{2}{a}, \underset{3}{a} \underbrace{*} h h<C R><L F>,
$$

where

hhmmss.ss - alarm transmission time (UTC);

1 - the signal level in the channel for receiving corrective information in the RCP:

$\mathrm{L}$ - the signal level at the receiving point is less than or equal to the receiver sensitivity; the alarm is triggered;

A - the signal level at the receiving point exceeds the receiver sensitivity; the alarm is reset;

2 - the signal-to-noise ratio in the channel for receiving corrective information in the $\mathrm{RCP}$ :

$\mathrm{L}$ - the signal-to-noise ratio below or equal to the threshold value; the alarm is triggered;

A - the signal-to-noise ratio exceeds the threshold value; the alarm is reset;

3 - the calculated error probability of an element-by-element reception of a digital message:

$\mathrm{H}$ - the error probability of the element-by-element reception of a digital message is greater than or equal to the acceptable value; the alarm is triggered;

A - the error probability of the element-by-element reception of a digital message is below the acceptable value; the alarm is reset; 
Based on the fact that the alarm message contains three parameters, which can take two values (L/A or H/A), the total number of possible combinations of RSIM message is eight. Each combination is assigned a specific code, which corresponds to a specific notification text for the user. Table 2 shows the possible combinations of three fields of the RSIM message (“ $\underset{1}{a}, \underset{2}{a}, \underset{3}{a}$ ” from formula (2)) and the corresponding alert texts displayed on the monitors of the operators of the remote control and management station (RCMS), the regional command and control center (RC\&CC) and the vessel traffic control center (VTCC), and Table 3 shows the alert text corresponding to the same combinations of three fields of the RSIM message, but already displayed on the skipper's display.

Table 2

RSIM messages transmitted to the operators of the RCMS, RC\&CC and VTCC

\begin{tabular}{|c|c|c|}
\hline No. & $a, a, a$ & ALERT TEXT \\
\hline 1 & $\mathrm{~L}, \mathrm{~A}, \mathrm{~A}$ & «low signal level of RS» \\
\hline 2 & $\mathrm{~L}, \mathrm{~L}, \mathrm{~A}$ & «low signal level, low SNR» \\
\hline 3 & $\mathrm{~L}, \mathrm{~L}, \mathrm{H}$ & «GNSS correction information is not reliable» \\
\hline 4 & $\mathrm{~L}, \mathrm{~A}, \mathrm{H}$ & «low signal level, high probability of error» \\
\hline 5 & $\mathrm{~A}, \mathrm{~L}$, & «low SNR» \\
\hline 6 & $\mathrm{~A}, \mathrm{~A}, \mathrm{H}$ & «high probability of error» \\
\hline 7 & $\mathrm{~A}, \mathrm{~L}, \mathrm{H}$ & «low SNR, high probability of error» \\
\hline
\end{tabular}

Table 3

RSIM messages transmitted to the skipper

\begin{tabular}{|c|c|c|}
\hline No. & $a, a, a$ & ALERT TEXT \\
\hline \multirow{4}{*}{1} & L,A,A or L,L,A or & «differential mode of RS “Name” \\
& L,L,H or L,A,H or & does not work» \\
& A,L,A or A,A,H or & A,L,H
\end{tabular}

$\mathrm{RCP}$
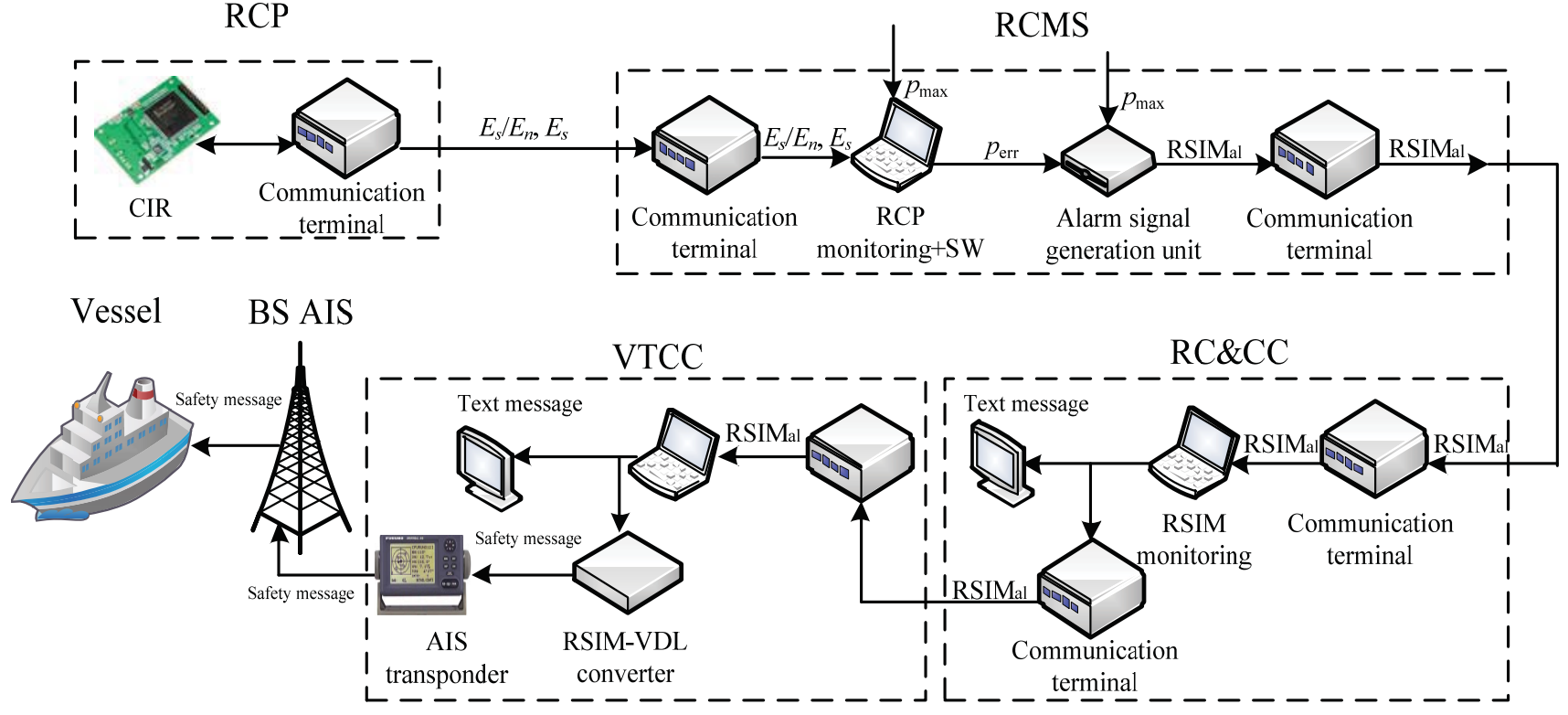

Fig. 1. The scheme of the automatic transmission of alarm messages:

RCP - remote control point; CIR - corrective information receiver; SW - software; RC\&CC - regional command and control center; VTCC - vessel traffic control center; BS AIS - base stations of AIS 


\section{Conclusion}

The paper presents a method for automatic transmission of alert signals in the M\&CS using the RTCM SC-104 version 1.2 standard, which describes the composition and transmission format of RSIM messages. The method is based on the calculation of the error probability of element-by-element reception of a digital message $p_{\text {err }}$. When this probability, calculated using the software installed in the RCMS, exceeds the permissible value $p_{\max }$, an alarm message $\mathrm{RSIM}_{\mathrm{al}}$ is generated in the RCMS and transmitted through the RC\&CC to the VTCC, where it is included in the short safety messages of the coastal AIS. These messages are received by the ship's AIS transponder, informing the user that the corrective information transmitted by this reference station is not reliable, and it cannot be used to calculate the position of the ship.

\section{References}

1. The official site of U.S. Department of Homeland Security (2017) "US Coast Guard (USCG) Maritime Differential GPS (DGPS) Locations", available at: https://hifld-geoplatform.opendata.arcgis.com/ datasets/9d8d139093a04877a65dd474d442c2e7_0?geometry=92.315\%2C 15.740\%2C66.827\%2C60.989 (Accessed 31 August 2020).

2. Specht C., Pawelski J., Smolarek L., Specht M., Dabrowski P. (2019). Assessment of the positioning accuracy of DGPS and EGNOS systems in the Bay of Gdansk using maritime dynamic measurements. The Journal of Navigation. Vol. 72. No. 3. P. 575-587. DOI 10.1017/S0373463318000838

3. (2010). Current and Planned Global and Regional Navigation Satellite Systems and Satellite-based Augmentations Systems. Austria: United Nations. 62 p.

4. Shi C., Wei N. (2020). Satellite Navigation for Digital Earth. In Manual of Digital Earth. Springer, Singapore, pp. 125-160.

5. IMO Resolution A.915(22). (2002). Revised Maritime Policy and Requirements for a Future GNSS. Adopted on January 22nd, 2002, London.

6. Shakhnov S.F., Ageeva A.A. (2017). Construction of control system of differential subsystem of GLONASS/GPS with use of the method of mathematical processing of signal parameters of differential correction. Herald of Admiral Makarov State University of Maritime and Inland Shipping. Vol. 9. No. 2. P. 402-413. DOI: 10.21821/2309-51802017-9-2-402-413.

7. Shakhnov S.F., Ivanova A.A. (2018). To the issue of formation of control and management system of the river differential subsystem of the global navigation satellite system GLONASS / GPS. River transport (XXI $I^{\text {st }}$ century). No. 2(86). P. 53-56.

8. Karetnikov V.V., Shahnov S.F., Ageeva A.A. (2018). Construction Method of Telecommunication System for Corrective Information Distribution. In IOP Conference Series: Earth and Environmental Science. Vol. 171, No. 1, pp. 1755-1315. DOI: 10.1088/1755$1315 / 171 / 1 / 012010$
9. Shakhnov S.F., Ivanova A.A. (2019). Constructing a control and management system with a warning subsystem for GNSS augmentation. Transport business of Russia. No. 5. P. 160-162.

10. Ober P.B. (2001). RSIM-based integrity monitoring for differential GNSS. In Proceedings of the 8th Saint Petersburg International Conference on Integrated Navigation Systems ,pp. 28-30.

11. Offermans G., Helwig A. (2003). Integrated navigation system eurofix: Vision, concept, design, implementation \& test. 302 p.

12. Offermans G.W.A., Helwig A.W.S., Van Willigen D. (1999). Eurofix system and its developments. The Journal of Navigation. Vol. 52. No. 2. P. 163-175. DOI: 10.1017/S0373463399008231

13. Chukin V.V. (2008). Application of network technologies in the construction of a system for remote sensing of the atmosphere using the global navigation satellite system. Fundamental research. No. 11. P. 58.

14. Tatarinovich B.A., Tarin A.A. (2014). Information technology for processing GPS log files. Mining informational and analytical bulletin (Scientific and technical journal). No. 9. P. 158-165.

15. Choi Y.K., Son S.B., Lee S.J. (2015). A Maritime DGPS Reference Station Configuration Proposal for Operation Improvement. Journal of Positioning, Navigation, and Timing. Vol. 4. No. 4. P. 187-193.

16. GOST R 55109-2012. (2013). The Global Navigation Satellite Systems. Maritime differential subsystems. The remote control and operation system. General requirements, methods of testing and required test results. Moscow: Standartinform. 73 p.

17. Wołejsza P. (2009). Data transmission in inland AIS system. Marine Navigation and Safety of Sea Transportation. Taylor \& Francis Group, 2009, pp. 405.

18. The official site of ITU. (2002). "Rec. ITU-R M.1371-1. Technical characteristics for a universal shipborne automatic identification system using time division multiple access in the VHF maritime mobile band”, available at: https://www.itu.int/rec/R-REC-M.1371-1-200108S/en (Accessed 31 August 2020).

19. (2002). Interim guidance on the use of an automatic information (identification) system (AIS) on ships and in shore services. Moscow: Ministry of Transport of the Russian Federation, State Marine Service. 58 p.

20. Certificate for equipment type approval No. SB-3/1-2967-2016 dated the $5^{\text {th }}$ August of 2016. Issued by the Federal Agency for Maritime and River Transport.

21. The official site of VPK news. (2018). "CCS-BS AIS”, available at: https://vpk.name/images/i203715.html (Accessed 1 November 2020).

22. (2019). Program and methodology for testing the equipment complex of the control and correction station and the base station of the automatic identification system during the formation and transmission of differential GNSS corrections via the VHF AIS channel. St. Petersburg: RIF company, Ltd. $32 \mathrm{p}$.

23. GOST R 56497-2015. (2015). Global navigation satellite system. Complex equipment for formed and transmission GNSS signal differential corrections on VHF AIS channel. General requirements, test methods and required test results. Moscow: Standartinform. 22 p. 


\title{
СПОСОБ АВТОМАТИЧЕСКОЙ ПЕРЕДАЧИ СИГНАЛОВ НАРУШЕНИЯ ЦЕЛОСТНОСТИ РЕЧНОЙ ЛОКАЛЬНОЙ ДИФФЕРЕНЦИАЛЬНОЙ ПОДСИСТЕМЫ
}

\author{
Иванова Александра Анатольевна, ГУМРФ имени адмирала С.О. Макарова, г. Санкт-Петербург, Россия, \\ uid@gumrf.ru \\ Шахнов Сергей Федорович, ГУМРФ имени адмирала С.О. Макарова, г. Санкт-Петербург, Россия, \\ shahnovsf@gumrf.ru
}

\section{Аннотация}

Целостность навигационной системы является одним из важных факторов, влияющих на безопасность судовождения. В настоящее время на внутренних водных путях России оповещения о целостности глобальной навигационной спутниковой системы (ГНСС) ГЛОНАСС передаются посредством речных локальных дифференциальных подсистем (ЛДПС), в состав которых входит одна или несколько контрольнокорректирующих станций (ККС). Индустриальные помехи от промышленных зон и линий электропередач (ЛЭП), взаимные помехи от соседних ККС и, особенно, неоднородность подстилающей поверхности оказывают влияние на дальность действия ККС, что приводит к нарушению целостности дифференциального поля и передаче судоводителю недостоверной корректирующей информации. Однако оповещения о некорректной работе ККС судоводителю не поступают. В результате, недостоверная корректирующая информация приводит к ошибкам при вычислении местоположения судна, что снижает уровень безопасности плавания. В работе представлен способ автоматической передачи оповещений о нарушении целостности ЛДПС от удаленной контрольно-управляющей станции (УКУС) на судно. Сформирована структура сообщения, передающего сигнал оповещения. Представлены критерии, характеризующие качество сигнала дифференциальной поправки (ДП). Выявлены возможные комбинации таких критериев, определяющие работоспособность дифференциального режима ККС. Каждой комбинации критериев сопоставлены соответствующие тексты оповещений, отображающиеся на мониторах операторов ЛДПС и на дисплее судоводителя. Разработана схема автоматической передачи сообщения тревоги от удаленного пункта контроля (УПК) через УКУС, региональный центр управления и контроля (РЦУК), центр управления движением судов (ЦУДС) и базовые станции автоматической идентификационной системы (АИС) на судовые транспондеры. В результате, разработанный способ передачи сообщения тревоги, содержащего комбинации критериев качества сигнала ДП, позволяет в автоматическом режиме информировать судоводителя о достоверности корректирующей информации, передаваемой той или иной ККС.

Ключевые слова: целостность навигационной системы, нарушение целостности, локальная дифференциальная подсистема, контрольнокорректирующая станция, сигнал оповещения, дифференциальная поправка, АИС.

\section{Литература}

I. US Coast Guard (USCG) Maritime Differential GPS (DGPS) Locations [Электронный ресурс]. Режим доступа: https://hifldgeoplatform.opendata.arcgis.com/datasets/9d8dI39093a04877a65dd474d442c2e7_0?geometry=92.3I5\%2CI5.740\%2C66.827\%2C60.989 (дата обращения: 31.08.2020).

2. Specht C., Pawelski J., Smolarek L., Specht M., Dabrowski P. Assessment of the positioning accuracy of DGPS and EGNOS systems in the Bay of Gdansk using maritime dynamic measurements // The Journal of Navigation. Vol. 72. 20I9. No. 3. P. 575-587. DOI: I0.10I7/S03734633।8000838

3. Current and Planned Global and Regional Navigation Satellite Systems and Satellite-based Augmentations Systems. Austria: United Nations, 2010. $62 \mathrm{p}$.

4. Shi C., Wei N. Satellite Navigation for Digital Earth. Manual of Digital Earth. Springer, Singapore. 2020. P. I25-I60.

5. Резолюция A.915(22) Пересмотренные требования мореплавания в отношении будущей глобальной навигационной спутниковой системы (ГНСС). Санкт-Петербург, 2002. 58 с.

6. Шахнов С.Ф., Агеева А.А. Построение системы контроля дифференциальной подсистемы ГЛОНАСС/GPS с использованием метода математической обработки параметров сигнала дифференциальной поправки // Вестник государственного университета морского и речного флота имени адмирала С.О. Макарова. 2017. Т. 9. № 2. С. 402-4I3. DOI: 10.2182I/2309-5180-2017-9-2-402-4I3

7. Шахнов С.Ф., Иванова А.А. Предпосылки создания системы контроля и управления речной дифференциальной подсистемой системы ГЛОНАCC/GPS // Речной транспорт (XXI век). 2018. № 2 (86). С. 53-56.

8. Karetnikov V.V., Shahnov S.F., Ageeva A.A. Construction Method of Telecommunication System for Corrective Information Distribution // IOP Conference Series: Earth and Environmental Science. IOP Publishing, 2018. Vol. I7I. Is. I. P. 012010. DOI: 10.1088/1755-13/5/171/1/0I2010

9. Шахнов С.Ф., Иванова А.А. Построение системы контроля и управления функциональным дополнением ГНСС ГЛОНАCC/GPS c подсистемой оповещения // Транспортное дело России. 2019. № 5. С. 160-162.

10. Ober P. B. RSIM-based integrity monitoring for differential GNSS //Proceedings of the 8th Saint Petersburg International Conference on Integrated Navigation Systems. 200I. C. 28-30.

II. Offermans G., Helwig A. Integrated Navigation System Eurofix - Vision, Concept, Design, Implementation \& Test. 2003.302 p.

12. Offermans G. W. A., Helwig A. W. S., Van Willigen D. Eurofix system and its developments //The Journal of Navigation. 1999. T. 52. №. 2. C. I63-175. DOI: $10.1017 / S 0373463399008231$

13. Чукин В.В. Применение сетевых технологий при построении системы дистанционного зондирования атмосферы с помощью глобальной навигационной спутниковой системы // Фундаментальные исследования. 2008. №II. С. 58.

14. Татаринович Б.А., Тарин А.А. Информационные технологии обработки файлов протоколов GPS // Горный информационно-аналитический бюллетень (научно-технический журнал). 20I4. № 9. С. I58-165. 
15. Choi Y. K., Son S. B., Lee S. J. A Maritime DGPS Reference Station Configuration Proposal for Operation Improvement //Journal of Positioning, Navigation, and Timing. 2015. T. 4. № 4. C. 187-193.

16. ГОСТ Р 55109-2012. Глобальные навигационные спутниковые системы. Морские дифференциальные подсистемы. система дистанционного контроля и управления. Общие требования, методы и требуемые результаты испытаний. М.: Стандартинформ, 2013. 73 с.

17. Woejsza P. Data transmission in inland AIS system // Marine Navigation and Safety of Sea Transportation. Taylor \& Francis Group, 2009. Pp. 405.

18. Rec. ITU-R M.I37I-I. Technical characteristics for a universal shipborne automatic identification system using time division multiple access in the VHF maritime mobile band [Электронный ресурc]. - Режим доступа: https://www.itu.int/rec/R-REC-M.I37I-I-200I08-S/en (дата обращения: 31.08.2020).

19. Временное руководство по использованию автоматической информационной (идентификационной) системы (АИС) на судах и в береговых службах. М.: Министерство транспорта Российской Федерации, Государственная служба морского флота, 2002. 58 с.

20. Свидетельство об одобрении типа аппаратуры № SB - 3/I - 2967 - 2016 от 05.08.2016 г. Выдано Федеральным агентством морского и речного транспорта. Действительно до 05.08.202I г.

2І. ККС-БС АИС // Новости ВПК [Электронный ресурс]. - Режим доступа: https://vpk.name/images/i2037I5.html (дата обращения: 0I.II.2020).

22. Программа и методика испытаний комплекса оборудования контрольно-корректирующей станции и базовой станции автоматической идентификационной системы при формировании и передаче дифференциальных поправок ГНСС по каналу УКВ АИС. Санкт-Петербург: Общество с ограниченной ответственностью "РИФ компания", 2019. 32 с.

23. ГОСТ Р 56497-20I5 Глобальная навигационная спутниковая система. Комплекс оборудования для формирования и передачи дифференциальных поправок сигналов ГНСС по УКВ каналу АИС. Общие требования, методы испытаний и требуемые результаты испытаний. М.: Стандартинформ, 2015. 22 с.

\section{Информация об авторах:}

Иванова Александра Анатольевна, аспирант кафедры судоходства на внутренних водных путях, ФГБОу ВО "ГУМРФ имени адмирала С.О. Макарова", Санкт-Петербург, Россия

Шахнов Сергей Федорович, д.т.н., доцент, профессор кафедры судоходства на внутренних водных путях, ФГБОУ ВО "ГУМРФ имени адмирала С.О. Макарова", Санкт-Петербург, Россия 